\title{
Perbedaan Persepsi Pasien Tentang Mutu Pelayanan Sebelum dan Sesudah Akreditasi di Puskemas Praya Kabupaten Lombok Tengah
}

\author{
Lalu Sulaiman $^{1{ }^{*}}$, Sastrawan ${ }^{1)}$, Sulwiyatul Kamariyah Sani ${ }^{2)}$, Muslim Tasim ${ }^{3)}$ \\ Email: sulaimanlalu@gmail.com \\ ${ }^{1)}$ Magister Administrasi Kesehatan Universitas Qamarul Huda Badaruddin \\ ${ }^{2)}$ Universitas Qamarul Huda Badaruddin \\ ${ }^{3)}$ Mahasiswa Program Studi Administrasi Kesehatan Universitas Qamarul Huda Badaruddin
}

\begin{abstract}
ABSTRAK
Akreditasi merupakan suatu upaya pemerintah untuk menjamin mutu pelayanan dalam hal ini yaitu pelayanan kesehatan. Pelayanan yang berkualitas bilamana pelayanan tersebut dapat memenuhi kebutuhan dan harapan pelanggan. Tidak hanya sampai disitu, pelayanan kesehatan yang berkualitas harus mampu mencegah terjadinya mal praktek (adverse event). Tujuan penelitian ini adalah untuk mengetahui apakah ada perbedaan persepsi pasien rawat jalan terhadap perbedaan mutu pelayaanan sebelum dan sesudah kegiatan akreditasi di Puskesmas Praya Kabupaten Lombok Tengah. Metode penelitian ini menggunakan metode kualitatif deskriptif dengan partisipan utama adalah pasien rawat jalan yang pernah berobat sebelum maupun sesudah akreditasi. Sedangkan partisipan (sasaran) antara adalah kepala dan para petugas yang ada di Puskesmas Praya. Hasil penelitian ini menunjukan ada perbedaan persepsi partisipan tentang penampilan fisik dan sarana yang ada di puskemas Praya. Dalam arti bahwa penampilan fisik dan sarana pelayanan yang tersedia jauh lebih baik setelah akreditasi. Kecepatan pelayanan jauh lebih cepat dengan waktu tunggu yang lebih singkat. Selain itu perilaku petugas dalam memberikan pelayanan serta kenyamanan pasien saat berobat jauh lebih baik dari pada sebelum akreditasi. Berdasarkan uraian diatas dapat disimpulkan bahwa mutu pelayanan kesehatan paska akreditasi jauh lebih baik dibandingkan dengan sebelum akreditasi. Diharapkan kepada kepala Puskesmas Praya dan jajarannya untuk mempertahankan mutu pelayanan kesehatan dengan menggunakan prinsip siklus PDCA.
\end{abstract}

Kata kunci: persepsi pasien; mutu layanan; akreditasi; puskesmas.

\begin{abstract}
Accreditation is an effort by the government to guarantee the quality of services especially in health services. A good service can de done if the service can meet the needs and expectations of customers. Not only that, quality of health services must be able to prevent the malpractice (adverse events). The purpose of this study was to determine whether there were differences in outpatient perceptions of differences in service quality before and after accreditation at Praya Health Center, Central Lombok. Research method was done by descriptive qualitative method with the main participants are outpatients who have received treatment before and after accreditation while the participants (targets) are head and officers at the Praya Health Center. The results of this study indicate that there are differences in participants' perceptions of physical appearance and facilities at the Praya health center. In the sense that the physical appearance and the availability of service facilities are much better after accreditation. The speed of services was much faster with shorter waiting time. In addition, the behavior of officers in providing services and patient comfort during treatment is much better than before accreditation. Based on the description above, it can be concluded that the quality of post-accreditation health services is much better than before accreditation. It is hoped that the head of the Praya Health Center and staff will maintain the quality of health services using the PDCA cycle principle.
\end{abstract}

Keywords: patient perception; quality service; accreditation; Public health center. 


\section{A. LATAR BELAKANG}

Program akreditasi puskesmas merupakan salah satu bentuk kebijakan pemerintah untuk mejamin mutu pelayanan puskesmas di seluruh Indonesia agar sesuai dengan standar yang telah ditentukan. Menurut Tawalujan, dkk. (2018), pelayanan dikatakan berkualitas atau memuaskan bila pelayanan tersebut dapat memenuhi kebutuhan dan harapan masyarakat, apabila masyarakat tidak puas terhadap suatu pelayanan yang disediakan maka pelayanan tersebut dapat dipastikan tidak berkualitas atau tidak efisien [1]. Guna menjamin bahwa perbaikan kualitas pelayanan kesehatan dilaksanakan secara berkesinambungan di puskemas, diperlukan adanya penilaian oleh pihak eksternal dengan menggunakan standar yang ditetapkan, yaitu melalui mekanisme akreditasi.

Tujuan dari pelayanan kesehatan yang sesuai standar melalui penetapan Standar Operasional Prosedur (SOP) adalah untuk menjamin jangan sampai terjadi apa yang disebut "Mal Praktek" atau sering dikatakan sebagai adverse event. Praktek semacam ini sering kali merugikan pasien dan sering berdampak buruk bagi pasien baik berupa kecacatan maupun kematian.

Dari hasil konferensi nasional yang diadakan di Program Studi S2 IKM Universitas Gadjah Mada tahun 2006, dikemukakan bahwa peristiwa adverse event pada pasien-pasien di Amerika Serikat melebihi angka kecelakaan lalu lintas. Di negara maju seperti di Amerika Serikat saja kejadiannya sangat besar apalagi di negara berkembang seperti di Indonesia. Oleh karena itulah pemerintah mulai memikirkan mutu pelayanan kesehatan di setiap institusi pelayanan kesehatan mulai dari pukesmas hingga fasilitas pelayanan kesehatan rujukan. Tiada lain tujuannya adalah untuk mengurangi atau mencegah terjadinya adverse event dan meningkatkan kepuasan pasien.

Menyadari akan hal ini pemerintah mulai melakukan upaya peningkatan mutu pelayanan keshatan melalui program Quality Assurance, program ISO 9000 di puskesmas-puskesmas dan saat ini melalui program akreditasi puskesmas. Penulis pernah melakukan studi banding di beberapa Puskesmas ISO yang ada di Kabupaten Jember Provinsi Jawa Timur pada tahun 2008. Hasil studi banding tersebut belum bisa diaplikasikan di Lombok Tengah waktu itu. Hal tersebut dikarenakan ukuran fisik ruangan seluruh puskesmas yang ada di Lombok Tengah belum ada yang memadai. Program ISO tidak hanya menyangkut masalah administrasi seperti ketersediaan protap untuk masing-masing jenis pelayanan akan tetapi ada standar ukuran fisik ruangan setiap jenis pelayanan kesehatan di puskemas. Pada saat itu, rata-rata ukuran fisik puskesmas-puskemas yang ada di Lombok Tengah dapat dikatakan masih minimalis.

Akreditasi Fasilitas Kesehatan Tingkat Pertama (FKTP) merupakan pengakuan yang diberikan oleh lembaga independen penyelenggara akreditasi yang ditetapkan oleh Menteri Kesehatan setelah memenuhi standar akreditasi [2]. Akreditasi puskesmas wajib dilakukan secara berkala paling sedikit tiga tahun sekali untuk menjamin peningkatan mutu secara berkesinambungan [3].

Program akreditasi di Kabupaten Lombok Tengah mulai tahun 2017 kegiatan akreditasi meliputi adminstrasi, usaha kesehatan masyarakat dan usaha kesehatan perorangan, laboratorium dan kefarmasian.

Puskesmas Praya sendiri mulai terakreditasi tahun 2017 dengan kategori "madya". Secara kasat mata penampilan pisik Puskesmas Praya setelah akreditasi memang lebih baik bila diandingkan dengan sebelum akreditasi. Oleh karena itu penulis tertarik untuk meneliti apakah ada perbedaan persepsi pasien tentang mutu pelayanan kesehatan sebelum dan sesudah adanya program akreditasi.

Tujuan umum penelitian ini adalah untuk mengetahui apakah ada perbedaan persepsi pasien tentang mutu pelayanan kesehatan sebelum dan sesudah adanya program akreditasi. Tujuan khususnya adalah untuk mengetahui persepsi pasien tentang: Penampilan atau Keberadaan sarana fisik dan sarana penunjang 
puskesmas, Kecepatan pelayanan, Sikap dan perilaku petugas pemberi pelayanan, Kenyamanan dalam pemberian pelayanan.

Manfaat secara umum dari penelitian ini adalah untuk memberikan informasi dan rekomendasi bagi para petugas dan para pengambil kebijakan di lingkungan Dinas Kesehatan Kabupaten Lombok Tengah tentang mutu dan upaya perbaikan mutu pelayanan kesehatan di Puskesmas Praya Kabupaten Lombok Tengah.

\section{B. METODE PENELITIAN}

Penelitian ini merupakan penelitian deskriptif-kualitatif. Informan primer dalam penelitian ini adalah pasien yang pernah berkunjung/berobat di Puskesmas Praya sebelum dan sesudah akreditasi. Informan sekundernya adalah para pejabat struktural dan fungsional yang ada di Puskemas Praya serta para stakeholders yang dianggap kredibel dibidang akreditasi puskesmas.

Informasi dikumpulkan melalui wawancara mendalam dengan menggunakan pedoman wawancara dan FGD. Informasi yang terkumpul akan dibuat dalam bentuk transkrip, untuk mengolahnya akan dilakukan melalui proses koding, kategorisasi dan penentuan tema-tema yang kemudian disajikan dan diuraikan dalam artikel ini.

\section{HASIL DAN PEMBAHASAN}

Persepsi yang terimplentasi dalam kepuasan pasien akan tercermin dalam minat seseorang terhadap jasa pelayanan berkaitan dengan kemampuan penyedia jasa pelayanan. Kepuasan pasien dapat didefinisikan sebagai big quality atau broad quality (kepuasan secara luas). Kepuasan secara luas tersebut terkait dengan mutu secara menyeluruh yang menyangkut mutu pelayanan dilihat dari aspek penampilan fisik puskesmas, kecepatan pelayanan, sikap dan prilaku petugas dan kenyamanan dalam pemberian pelayanan.

Setelah melalui proses pengolahan data ditemukan tema-tema sebagai berikut:

\section{Penampilan Fisik Puskemas Praya.}

Dari hasil wawancara mendalam dengan informan ditemukan bahwa perlengkapan fisik Puskesmas Praya termasuk perlengkapannya jauh berbeda sebelum dan sesudah akreditasi. Mereka mengatakan bahwa dahulu gedung puskemas Praya kurang bersih, ruang tunggu pasien masih dihalaman atau diluar gedung, hanya ada bangku yang terbuat dari kayu sebagai tempat duduk pasien sementara menunggu namanya dipanggil oleh petugas loket. Ruang loket (tempat penerimaan pasien) menghadap keluar gedung (menghadap halaman). Terkadang pasien terkena terik matahari bila jumlah kerumunan pasien cukup banyak.

Saat ini ruang tunggu sudah ada didalam gedung. Bangku tunggu sudah terbuat dari baja yang nyaman diduduki, Ruang tunggu dilengkapi AC. Saat ini pasien tidak terkena terik matahari dan hujan pokoknya terasa lebih nyaman dari pada sebelum akreditasi.

Seorang informan mengatakan:..... "Ruang tunggu Puskesmas Praya saat ini jauh lebih nyaman. Lokasinya didalam gedung, ada AC nya, tempat duduk bagus nyaman rasanya dan ruangannya juga cukup luas. Kalau dahulu ruang tunggu ada diluar termasuk tempat antrean saat ambil obat juga terletak di luar. Terkadang terkena sinar matahari, karena ruang loket dan apotik sama-sama menghadap keluar (halaman)". (Wawancara dengan Hj. Rky 40 tahun).

Selain itu menurut informan lainnya, ruang pelayanan pasien seperti ruang perksa, ruang laboratorium, ruang apotik, KIA, dan lainnya keadaannya sangat memadai jika dibandingkan dengan keadaan dahulu ketika belum ada akreditasi. Begitu juga ruang penunjang lainnya seperti kamar mandi dan musholla sangat terjaga kebersihannya.

Seorang informan mengatakan:...."Ruang pelayanan pasien saat ini lebih luas, bersih dan rapi. Alur pelayanan jelas karena ada bagan alur pelayanan tertempel di tembok serta ada panah penunjuk arah. Kita tidak bingung jadinya". (Wawancara dengan H.Gbh, 65 tahun), 
juga yang mengatakan: ..... "sekarang kalau mau buang air WC nya bersih, tidak berbau, air tidak pernah mati. Musholla untuk sholat juga bersih. Tersedia tempat wudhu yang memadai". (Wawancara dengan Mar, 37 tahun).

Dari petikan wawancara diatas terlihat bahwa dari segi keadaan sarana fisik Puskesmas Praya menurut penilaian dan persepsi pasien jauh lebih baik atau lebih memadai dibandingkan keadaan sarana fisik puskesmas sebelum akreditasi. Kondisi semacam ini akan memberikan kesan bagi para pasien bahwa upaya akreditasi telah memberikan rasa nyaman bagi mereka. Hal ini sesuai dengan hasil penelitian Taekab, A H., Suryawati, C., Kusumawati, W (2019) yang mengatakan bahwa unsur tangable seperti penampilan pisik puskesmas berhubungan secara signifikan dengan kepuasan pasien [4]

\section{Kecepatan Pelayanan}

Kecepatan pelayanan terutama lama waktu tunggu (antrean) merupakan salah satu indikator yang digunakan oleh pasien untuk menilai mutu pelayanan di sarana pelayanan kesehatan. Orang selalu mengatakan bahwa menunggu lama merupakan hal yang membosankan.

Dari hasil wawancara dengan informan, ratarata mereka mengatakan bahwa waktu tunggu saat ini jauh lebih singkat dari pada sebelum akreditasi. Serang informan mengatakan:

...." Dahulu begitu kita datang di puskesmas, kita berikan kartu pengunjung kepetugas loket. Lama baru kita dipanggil karena menungggu giliran saat petugas mencari berkas pasien. Begitu dipanggil banyak hal-hal yang ditanyakan terutama yang menyangkut identitas pasien dan keluarga. Apalagi kalau lupa bawa kartu pengunjung proses pencarian berkas akan lebih lama lagi. Kalau rumah kita dekat biasanyapetugas menyuruh kita pulang cari kartu pengunjung. Begitulah dahulu. Nah sekarang tidak perlu itu,cukup bawa kartu BPJS. Petugas secara cepat dan secara otomatis akan menemukan data kita di komputer jadi proses cepat tidak ribet".
Menurut mereka, saat ini prosesnya gampang. Kita tidak perlu membawa berkas sendiri menuju ruang pelayanan berikutnya. Apakah ke ruang periksa, laboratorium, ruang suntik atau ruang pengambilan obat. Semua sudah terhubung secara otomatis melalui jaringan komputer. Ada juga pasien yang mengatakan:....." pokoknya saat ini, waktu yang diprlukan sejak baru datang ke puskesmas sampai pulang jauh lebih singkat dibandingkan dengan yang dulu-dulu. Ini mungkin karena pelayanannya serba computer". Maksud mereka bahwa pelayanan di puskesmas serba komputer adalah karena sistem pelayanan kesehatan di Puskemas Praya sudah serba digital melalui local area network (LAN). Dengan demikian prosesnya menjadi lebih cepat guna mewujudkan daya tanggap/ responsiveness yang baik guna membantu pasien memenuhi harapannya, misalnya waktu yang diperlukan petugas kesehatan untuk memberikan informasi yang jelas, menyelesaikan keluhan pasien dan tindakan yang cepat pada saat pasien membutuhkan.

Menurut Hanum, F (2020) mengatakan salah satu dimensi mutu pelayanan adalah memberikan pelayanan dengan waktu yang tepat sesuai waktu yang dibutuhkan, sebagaimana tertera dalam standar pelayanan [5]. Dalam memberikan pelayanan, petugas sebaiknya menggunakan waktu sebaik - baiknya yaitu tidak terlalu lama. Pemeriksaan atau pelayanan yang terlalu lama cenderung mengakibatkan pasien atau pelanggan yang dilayani bosan / jenuh dan menganggap bahwa petugas tidak professional (terkesan lambat) serta akan mengakibatkan antrean yang panjang di loket pendaftaran atau loket pembayaran.

\section{Sikap dan Perilaku Petugas}

Sikap dan perilaku petugas pemberi pelayanan kesehatan merupakan salah satu indikator mutu pelayanan. Petugas yang selalu senyum dan ramah-tamah dalam memberikan pelayanan kesehatan kepada pasien akan akan memberikan kesan yang baik bagi pasien dalam menerima pelayanan. Sikap dan perilaku 
semacam itu akan memberikan sugesti postif bagi kesembuhan pasien.

Tidak ada artinya gedung yang megah alat yang serba canggih kalau sikap dan perilaku petugas kurang baik dalam memberikan pelayanan. Oleh karena itu sejak adanya akreditasi puskemas semua petugas berkomitmen untuk memberikan pelayanan yang terbaik dengan mengutamakan sifat kekeluargaan, selalu senyum dan ramah tamah sehingga pasien merasa diperlakukan seperti keluarga sendiri dalam arti pasien tidak dianggap sebagai orang asing yang merasa diasingkan oleh petugas. Model pelayanan semacam ini menyebabkan kesetiaan pasien untuk meminta pelayanan kesehatan di Puskemas Praya tetap tinggi. Keadaan inilah yang menyebabkan terjadinya peningkatan visite rate di Puskemas Praya. Seorang petugas mengatakan:....."bahwa sejak adanya akreditasi kami telah menandatangani kesepakatan bersama bahwa kami berkomitmen untuk selalu memberikan pelayanan kesehatan terbaik dengan senyum dan ramah-tamah serta penuh kekeluargaan". Komitmen petugas semacam ini memang sangat diperlukan didalam menjaga kesinambungan pelayanan kesehatan yang berkualitas, yaitu pelayanan yang emphaty, kemudahan dalam melakukan hubungan, komunikasi yang baik, perhatian pribadi dan memahami kebutuhan pasien dengan tetap menunjukkan adanya perhatian petugas kesehatan dengan setiap keluhan pasien dan keluarganya.

Dalam melaksanakan pelayanan tentunya tak terlepas dari sikap dalam menghadapi pelanggan atau contact personal. Hal ini merupakan aspek yang penting dalam menentukan kualitas dalam pemberian pelayanan. Untuk mencapai hal ini, maka performance atau penampilan yang baik dan rapi turut mendukung dengan sikap ramah, memperlihatkan gairah kerja, sikap siap melayani, tenang dalam bekerja,mengetahui dengan baik pekerjaannya baik yang berhubungan dengan tugas unitnya maupun unit lain, mampu berkomunikasi dengan baik dan mampu menangani keluhan pelanggan.
Kepuasan terhadap proses pelayanan kesehatan terkait erat dengan hubungan antar manusia. Oleh karena itu sikap dan perilaku petugas dalam memberikan pelayanan kesehatan sangat penting artinya [6]. Performa petugas akan menentukan tingkat kepercayaan dan keyakinan kepada tenaga kesehatan, termasuk tingkat keyakinan pasien akan kesesuaian diagnosa dan obat yang diberikan. Semua ini akan mempengaruhi tingkat kesetiaan pasien untuk berkunjung di sarana pelayanan kesehatan.

\section{Kenyamanan dalam pemberian pelayanan}

Kenyamanan merupakan salah satu unsur dari mutu pelayanan. Rasa nyaman yang diterima pasien selama proses pelayanan akan membuat pasien menjadi senang dan betah berada di tempat tersebut. Salah seorang pasien mengatakan:

...." disini saya merasa betah, tempatnya nyaman, tidak ada suara yang rebut, petugasnya ramah tamah, tempat duduknya enak pokoknya nyaman dah". Memang kalau diperhatikan kondisi di Puskesmas Praya secara riilnya sama dengan apa yang disampaikan oleh seorang pasien. Tidak ada suara ribut karena mereka sudah bekerja secara digital yang terhubung melalui system jaringan sehingga petugas tidak perlu saling panggil-memanggil atau sahutsahutan bila satu sama lain diantara petugas saling membutuhkan. Saat ini sistim komunikasi mereka sudah melalui jaringan komputer sehingga tidak perlu bersuara. Suasanapun menjadi tenang, tempat duduk untuk menunggu giliran juga memadai, ruangan ber AC sehingga terasa nyaman. Menurut mereka keadaan ini jauh berbeda dari keadaan sebelum adanya akreditasi.

Kenyamanan ini merupakan salah satu unsur tangable dimana menurut Taekab, A H., Suryawati, C., Kusumawati, W (2019) mengatakan bahwa ada hubungan yang bermakna antara unsur kenyamanan dengan kepuasan pasien.

Selain tersebut di atas, untuk dapat memberikan pelayanan yang nyaman dan memuaskan bagi pengguna jasa, 
penyelenggaraan pelayanan harus memenuhi asas- asas pelayanan. Berdasarkan Keputusan Menpan Nomor 63 Tahun 2004 yang menyatakan bahwa asas-asas pelayanan meliputi: transparansi, akuntabilitas, kondisional, partisipatif, kesamaan hak dan keseimbangan hak dan kewajiban [7].

\section{KESIMPULAN}

Berdasarkan hasil penelitian tersebut dapat disimpulkan bahwa: 1) Keadaan sarana fisik Puskesmas Praya menurut penilaian dan persepsi pasien jauh lebih baik atau lebih memadai dibandingkan keadaan sarana fisik puskesmas sebelum akreditasi. 2) Kecepatan pelayanan sudah baik, tidak membuat pasien lama menunggu karena didukung oleh system komputerisasi. 3) Sejak adanya akreditasi puskemas, semua petugas berkomitmen untuk memberikan pelayanan yang terbaik dengan mengutamakan sifat kekeluargaan, selalu senyum dan ramah tamah sehingga pasien merasa diperlakukan seperti keluarga sendiri dalam arti pasien tidak dianggap sebagai orang asing yang merasa diasingkan oleh petugas. 4) Kenyamanan dalam meenrima pelayanan di Puskesmas Praya setelah akreditasi jauh lebih nyaman, tidak rebut, ruangannnya ber AC dan system antrian sudah memakai sistem komputersisasi.

\section{DAFTAR PUSTAKA}

[1] Tawalujan, et.al. (2018), Hubungan Antara Status Akreditasi Puskesmas Dengan Tingkat Kepuasan Pasien Di Kota Manado, Jurnal KESMAS, Vol. 7 No. 5.

[2] Direktorat Mutu dan Akreditasi Pelayanan Kesehatan (2017)

[3] Peraturan Menteri Kesehatan RI Nomor 46 Tahun 2015 Tentang Akreditasi Puskesmas, Klinik Pratama, Tempat Praktik Mandiri Dokter dan Dokter Gigi

[4] Taekab, A H., Suryawati, C., dan Kusumawati, W (2019), Analisis Persepsi Pasien Terhadap Mutu Pelayan Puskesmas dan Hubungannya Dengan
Kepuasan Pasien Rawat Jalan di Puskesmas Leyangan Kabupaten Semarang Tahun 2018, Jurnal Kesehatan Masyarakat, Vol. 7 No.1.

[5] Hanum, F. (2020), Terapkan Tujuh Dimensi Mutu Pelayanan Kesehatan, Direktorat Jenderal Pelayanan Kesehatan, Kementerian Kesehatan RI.

[6] Pohan, Imbolo (2007), Jaminan Mutu Layanan Kesehatan, Penerbit Buku Kedokteran. ECG, Jakarta.

[7] Keputusan Menteri Pendayagunaan Aparatur Negara Nomor: 26/KEP/M.PAN/2/2004 Petunjuk Teknis Transparansi dan Akuntabilitas dalam Penyelenggaraan Pelayanan Publik. 